\title{
Understanding foreign language education and bilingual education in Belgium: a (surreal) piece of cake
}

\author{
Laurence Mettewie and Luk Van Mensel
}

NaLTT, UNamur, Belgium

ABSTRACT

The aim of the present article is to provide an overview of the current state of affairs regarding foreign language education and bilingual education in the different parts of Belgium. In a brief historical contextualisation, we explain how language education in Belgium has been shaped by the country's political and economic history, which has led to legal constraints concerning the language(s) of instruction as well as foreign language education. A paradoxical situation has now emerged: on the one hand, an apparently straightforward organisation of language education according to a 'one community - one language' principle; on the other hand, a complex and heterogeneous reality with respect to the organisation of the school system in general and language education in particular. We illustrate the present situation with figures from the different language communities (Dutch-, French-, and German- speaking) on (a) foreign languages learned at school in regular settings, and (b) alternatives to the regular framework that bypass the constrictive legislation, such as CLIL. The data reveal the intricate make- up of language education in Belgium, reflecting a tailor-made approach taken by each of the three official language communities.

KEYWORDS

Belgium; foreign language education; bilingual education; CLIL; Dutch; English/EFL

Will Brussels get a multilingual school? ${ }^{1}$ It was a question that was tackled in March 2019 in French - and Dutch-language Belgian daily newspapers. The rectors of two universities in Brussels (one Frenchspeaking, the other Dutch-speaking) expressed their determination to overcome any legal obstacles in order to start up a multilingual school in the capital of Belgium as soon as possible, where students would be taught in French, Dutch, and English. Since this capital is officially bilingual and situated in a country with three official languages, such a statement about the obstacles facing the implementation of bi- or multilingual education may come as a surprise. This paper will try to shed light on how the current sociopolitical structure of this federal country, shaped by its economic and political history, determines foreign language education, and why bilingual education is officially 'illegal' but still exists in tailor-made formats across the country.

\section{Belgium: striking a balance between history, reality and symbols}

Belgium is a small state of about 11 million inhabitants, ${ }^{2}$ squeezed between European giants such as France, Germany and the UK and renowned for its chocolates, waffles and beers, but also for being an absolute champion in translating compromises into institutional complexity (Witte and Van Velthoven 2010). The federal structure is based on three Regions and three Communities, each having distinct areas of competence and geographical reach. The Regions are mainly responsible for territorial matters (town planning, transport, environment, water, energy, economy, etc. $)^{3}$ and are subdivided as follows: Flanders in the north (Vlaams Gewest, 6,552,967 inhabitants), being theoretically monolingual Dutch, Brussels in the centre (Brussels Hoofdstedelijk Gewest/Région de Bruxelles-Capitale, 1,198,726 inhabitants), which is officially bilingual, and Wallonia in the south (Région wallonne, 3,624,377 inhabitants), considered monolingual French, except for the eastern part, where German is the official language. Unlike the Regions, the Language Communities are responsible for personal matters, including culture, health prevention, social services, research, and, most relevant for this paper, education. ${ }^{4}$ These Communities are split up into a Dutch-speaking demographic majority (Vlaamse Gemeenschap) that mainly lives in Flanders and as a minority in Brussels, a French-speaking Community, commonly called Communauté française WallonieBruxelles to emphasise its presence across two Regions, and finally the German-speaking minority (Deutschsprachige Gemeinschaft), with about 77,000 inhabitants, located in the eastern part of Wallonia. ${ }^{5}$ This means that the Belgian Communities and Regions only partially overlap geographically (for maps, see belgium.be ${ }^{6}$ ). 
To complicate the picture even more, the assumed linguistic homogeneity of the Regions has some exceptions along the linguistic border (defined by law in 1963) and around Brussels, as 27 municipalities ${ }^{7}$ belonging to one Region provide language 'facilities' at the administrative and educational level (Janssens 2013; see below) for members of the minority language group (defined as representing more than $30 \%$ of the population as registered in the 1947 census). Due to demographic changes in language dominance in these municipalities and the fact that no language census has been allowed since $1947^{8}$ so as to prevent any territorial claims and readjustments (McRae 1986; Treffers-Daller 2002), these 'facilities' have been challenged in the past few decades, even fiercely disputed, though never settled (Goossens and Cannoot 2015; Mnookin and Verbeke 2009).

The constant exercise of balancing the power of the different Communities and Regions in Belgium is burdened by a socio-economic, cultural and political heritage that is characterised by two key facts. The first is a lack of recognition of Dutch (or 'Flemish' as quoted in the 1898 law, ${ }^{9}$ stressing its perceived low status, as some politicians even considered it 'a joke', see Morelli and Mettewie 1994) as an official language at different societal levels until the (late) twentieth century (Vogl and Hüning 2010; Willemyns 2003). The second fact is the reversing economic gravity in the 1960s from the old Walloon steel and coal industries in the south to the Flemish chemical and portrelated industries in the north (Van der Sijs and Willemyns 2009, 284; Witte and Van Velthoven 2010, 166). This change has led to socio-political emancipation and economic prosperity in Flanders and to economic decline in large parts of Wallonia. As a corollary, the Dutch language gained prestige and surpassed French as the elite language in Flanders in the course of the twentieth century, bringing about a strong attachment to the symbolic use of the language as an expression of one's position, courtesy and openness (or not) towards the 'other' linguistic community. An example of that symbolic role of language can be found in the political crisis that prevented the formation of a new government and lasted for 526 days after the June 2010 elections. During the negotiations, there was a radical polarisation of political forces according to their language affiliation. This polarisation has been going on for many years in the Belgian media, presenting Francophones and Flemish (or Dutch-speakers) as opposing camps, 'us' against 'them' (Sinardet 2008; Potvin, Morelli, and Mettewie 2004). During the negotiations, one of the recurrent stings reported in the media was the poor knowledge of Dutch of some Francophone politicians, including the Prime Minister to be, Elio Di Rupo, which was perceived as a form of contempt (some called it 'raping the language' ${ }^{10}$ ). Hence, in his first speech in parliament, on 7 December $2011{ }^{11}$ the Prime Minister promised to improve his knowledge of Dutch to symbolically affirm his openness towards the Dutch-speaking Community and his willingness to be the Prime Minister of all Belgians.

The consequences of the amalgamation of the symbolic role of languages in Belgium and the quest for balanced power relationships between Language Communities and Regions are starkly illustrated by in (a) the organisation of the language education system and (b) the development of bilingual programmes.

\section{Language(s) of instruction in education: basic principles}

Given the context described above, the educational system in Belgium has been organised independently by the three Communities since the 1980s. However, the language of instruction is linked to the principle of territoriality and consequently depends on the Region in which the schools are located; the national law of 1963 on language use in education ${ }^{12}$ stipulates that the only language of instruction should be the language(s) of the Region (Witte and Van Velthoven 2010). Bringing different pieces of the institutional jigsaw puzzle together, this means that in the Flemish Region, education is organised by the Dutch-speaking Community, with Dutch as the only language of instruction. In the Walloon Region, education is the responsibility of the French-speaking Community and French is the sole language of instruction, except in the German-speaking area, where the German-speaking Community is in charge of education and German is the principal language of instruction. Since the Brussels-Capital Region is officially bilingual, both the Dutch-speaking and the French-speaking Community are in charge of education.

In Brussels, the fact that both Language Communities share responsibility does not mean that they coorganise education, but rather that there are two parallel systems from pre-school through to university, one in Dutch and one in French. Based on a regulation from 1914 concerning the 'freedom of the head of the family' ('la liberté du père de famille'; for details, see Deprez et al. 1982; Treffers-Daller 2002), all parents living in Brussels can choose to send their children to whichever school (offering whichever 
language of instruction) they prefer, which has led to many 'crossovers'. Until the 1970s this was mainly the case for Dutch-speaking children receiving French-medium education because of the higher prestige of French and the upward social mobility with which parents associated the language (Treffers-Daller 2002). However, the 1973 legislation allowed the Dutch minority schools to offer far more attractive education thanks to major financial investments intended primarily - but not exclusively - for the Dutch-speaking minority (Deprez et al. 1982; Treffers-Daller 2002; Janssens, Carlier, and Van de Craen 2009). In the past thirty to forty years, there has been a shift in the direction of pupils' movements, as nowadays mainly nonDutch-speaking pupils (French and/or other languages) attend Dutch-medium schools in Brussels, creating a large linguistic heterogeneity within these theoretically Dutch minority language schools. ${ }^{13}$ This clearly challenges schools' organisation and capacities, but at the same time creates a unique contact situation between young people from different language communities (Ceuleers 2008; Janssens 2007, 2009; Jaspers 2015; Mettewie 2007).

There is another situation in which some parents can choose between French- or Dutch-medium education, namely in the 27 municipalities offering 'facilities' for the other language community in areas such as education (see above). ${ }^{14}$ This means that, for instance, in the commune of Ronse (Renaix in French) in the Flemish Region French-speaking parents can ask for pre-school and primary school in French, financed by the Flemish Community, ${ }^{15}$ and vice versa for the Walloon municipality of Mouscron (Moeskroen in Dutch) for its Dutch-speaking population, or for German-speakers in the Walloon municipality of Malmédy. ${ }^{16}$ In all other cases, parents are expected to send their children to schools in the language of the Region they live in. ${ }^{17}$

A common feature for the three Language Communities is the general structure of the different stages of education, starting with non-compulsory, but very popular pre-school education for three years (age 3-6 approximately), followed by six years of primary school, numbered from Years 1-6 (age 6-12 approximately), and ending with at least six years of secondary education (Years 1-6), with different general, vocational or technical streams. Education is compulsory from primary school until the age of 18 , but can be part-time in vocational programmes. Each Language Community also has an intricate system of educational networks, with public State-run education (guaranteeing philosophical and religious neutrality ${ }^{18}$ ), subsidised public schools organised by cities, municipalities or provinces, and subsidised private education based on religious (mainly Catholic) and pedagogical principles (Montessori, Freinet, Steiner, etc.). They are all allowed to have their own specific curriculum as long as it is validated and recognised by the Education ministry and complies with language legislation and other types of legislation. Shortage of space means that we cannot go into further detail regarding the differences between the networks.

To sum up, in a country with three official languages and bilingual or linguistically mixed Regions, no bilingual education provisions have been made. On the contrary, strict legislation, inherited from a sociopolitical past, mandates through different laws and decrees not only the (single) language of instruction, but also where, when, how and what languages can be learned at school through mainstream second or foreign language (FL hereinafter) classes. How this has been customised according to the Communities and Regions is detailed in the next section.

\section{Foreign language education in Belgium}

Regardless of the commonalities, the main difference between the Language Communities lies in the amount of FL teaching a week, the age of onset of FL learning and the choice of foreign language(s). Table 1 summarises the different scenarios regarding language of instruction and FL education, excluding any additional language courses outside the regular school timetable (Chinese, Romanian, Italian, Turkish, Polish, ... in schools of the French-speaking Community).

We will start by describing the smallest (German-speaking) Community, with the most intensive FL learning programmes, before moving on to the Dutch-speaking Community and ending with the more complex situation in the French-speaking Community. 


\subsection{FL education organised by the German-speaking Community}

Despite its proximity to Germany, the Deutsche Gemeinschaft, nestled within the French-speaking Walloon Region, is very much aware of its minority status and the fragile position of German in Belgium (Boemer and Darquennes 2015; Bouillon 2018; Darquennes 2013; Greten 2008). The German Community's language policy is deliberately aimed at supporting German as a Community language, while guaranteeing that pupils will be integrated into the wider Walloon Region and will have access to higher education, which is available mainly in French in the surrounding area (Bouillon 2018). Multilingualism is therefore considered an important prerequisite for social and cultural development as well as for professional success (Ministerium der Deutschsprachigen Gemeinschaft Belgiens, March $2019^{19}$ ). As a result, pupils in German-medium schools receive a considerable amount of teaching of French as a compulsory first foreign language (FL1 hereinafter). ${ }^{20}$ In preschool, children already have 50-200 min of French a week, preferably for short periods on a daily basis (in two pilot projects, even up to $350 \mathrm{~min}$ a week). At primary school level, pupils start with 2-3 h of French a week in Years 1 and 2, increasing to 3-4 h in Years 3 and 4, and to $5 \mathrm{~h} \mathrm{a}$ week in Years 5 and 6. This means that, in a 36-week school year, children attending German-medium schools have between 828 and 1296 h of French FL before starting secondary school. Moreover, in order to support their FL classes, primary school pupils can also be taught music, art and physical education (PE) in French. This is not considered bilingual education, though this way of teaching subjects through the target language is very similar to the European CLIL type of education (Eurydice 2006), which we will discuss later. At secondary level, pupils continue FL learning with a minimum of $4-5 \mathrm{~h}$ a week of French (2 $\mathrm{h}$ a week in vocational education) and the option of having 2-5 h of English weekly, in addition to $2 \mathrm{~h}$ of Dutch (from Year 3 on) or Spanish (in Year 5 and the final year). As in primary school, pupils can also have classes taught in French besides the regular FL classes, which are detailed in the section on bilingual education. To complete the picture of FL education in the German-speaking area, we should mention that in a few municipalities with 'facilities' for French- speakers, such as Eupen, there are some French-medium schools in which German is the compulsory FL1, as the German-speaking Community is in charge of them.

\subsection{FL education organised by the Dutch-speaking Community (Flanders and Brussels)}

In Dutch-medium education, the main focus in the language policy for the past few decades has been to ensure that pupils have a thorough knowledge of Dutch, in combination with prestigious foreign languages. Pupils therefore have Dutch as the main language of instruction and compulsory French classes from Year 5 of primary school onwards ( 2 hrs/week). Article 43 of the 1997 Decree on primary education ${ }^{21}$ also allows schools to start earlier with optional French classes, as well as English and German from Year 3, and even have FL initiation in pre-school. Some reports mention French initiation classes (Peiling Frans in het basisonderwijs 2018, 21), however, this option is not referenced in any of the current school curricula made available online by the educational authorities. ${ }^{22}$ In any case, before starting secondary school, pupils in Flanders will have had a minimum of $144 \mathrm{~h}$ of French.

In the bilingual area of Brussels, Dutch-medium schools are allowed to organise French FL classes from Year 1 of primary school onwards, but only if pupils already have 'a sufficient level' of proficiency in Dutch (cf. Art. 43). What that level should be is not detailed, but again echoes the concerns of the Dutch-speaking Community about losing its grip on its language of instruction. Broadly speaking, this can be traced back to Dutch being a minority language within the context of Brussels and until the 1970s being under pressure in the educational sphere (Deprez et al. 1982). However, and as mentioned earlier, since the 1980s Dutchmedium education in Brussels has become very attractive to non-Dutch-speaking parents and pupils as well. $^{23}$

At secondary level, French is also the compulsory FL1, with traditionally more teaching hours than the FL2, English. Recent changes in programmes allow schools to reinforce English by reducing the hours of French, which is considered to be an alarming evolution by French language teachers and academics. ${ }^{24}$ Depending on their chosen study programme, pupils can also have additional FL instruction in Spanish and German, with in all cases between 2 and $4 \mathrm{~h}$ a week for each FL, mainly in the last stages of secondary education. In secondary schools, FLs are generally taught by trained language teachers, whereas at primary level, the regular class teachers are in charge of French classes. These primary teachers are expected to have a CEFR level of B1 for reading and writing and B2 for understanding and speaking French (cf. Common European Framework of Reference for Languages ${ }^{25}$ in order to be able to teach the language in an interactive way. ${ }^{26}$ 
School inspectors and researchers often note that in-service and prospective primary school teachers do not have the required level, which is said to jeopardise lively, correct and spontaneous interaction within the FL classes, contributing to the lack of appeal of French classes and the lower results obtained (Peiling Frans in het basisonderwijs 2018; Vlaamse Onderwijsinspectie 2017a; Leemans $2018^{27}$ ).

The fact that French (and not English) is the compulsory FL1 in Flanders sometimes prompts complaints from certain parts of the public, but so far has not resulted in any shift in policy. One possible explanation could be that successive Education ministers have maintained French as compulsory FL1 partly for symbolic reasons (as the language of the 'other' main community), but also for economic reasons, aware that French is an asset in the job market in Belgium and elsewhere (Beleidsnota Onderwijs 2014-2019). In more practical terms, being sensitive to the decline in French proficiency among Dutch-speaking pupils ${ }^{28}$ and primary teachers, and realising that, despite often fewer teaching hours, the standard of English is nevertheless higher compared with French (Housen, Janssens, and Pierrard 2003; Declercq, Denies, and Janssen 2012) due to its higher prestige and pupils' extensive exposure to English outside school (Peters 2018; De Wilde, Brysbaert, and Eyckmans 2020), policymakers, so far, seem to opt for maintaining French as a compulsory FL1 to ensure maximum opportunities to acquire the language within an educational context (Beleidsnota Onderwijs 2014-2019).

\subsection{FL education organised by the French-speaking Community (Wallonia and Brussels)}

Unlike in Flanders, pupils in French-medium schools in Wallonia can choose their FL1 depending on what their school offers, as each school decides, with its advisory board ('conseil de participation'), in which languages (maximum two) the FL classes will be taught. This was facilitated by a decree proposed in 1974 and eventually adopted in $1980^{29}$ after intense political debate (cf. Rapport de Commission, ${ }^{30}$ Vandeputte 1979). The option to choose exists now at both primary and secondary level and the FL chosen can change at particular points in time. ${ }^{31}$ This means that today pupils can alternate between one FL and another, although this is not encouraged. The 1998 decree $^{32}$ stipulates a minimum of $2 \mathrm{~h}$ a week for Years 5 and 6 in primary education in Wallonia. In addition to the FL classes, if schools have the resources and the qualified staff and if it is part of a specific school project, they can offer additional language classes up to 2 $\mathrm{h}$ a week (Years 1-4; max. $1 \mathrm{~h}$ for Years 5 and 6).

In Brussels and in municipalities with 'facilities', Dutch is non-elective and starts in Years 3 and 4 with $3 \mathrm{~h}$ a week and ends with $5 \mathrm{~h}$ in Years 5 and 6. These schools have the option of offering FL instruction (in Dutch or, for the few municipalities close to the German-speaking area, also in German) as early as Year 1, with $2 \mathrm{~h}$ a week (cf. Dutch-medium schools in Brussels). At secondary level, pupils in Brussels have Dutch as FL1, but can choose a FL2 or FL3 from English, German, Dutch and Spanish. The number of hours per week depends on the study programme chosen and type of education (general, technical or vocational). The same is true for Wallonia, except that pupils there can also choose their FL1, depending on what the school proposes, and that for the FL2 and FL3 some schools also offer Italian and recently Russian.

The media regularly report on the increasing success of English and declining popularity of Dutch as an FL1 in Wallonia. The figures for secondary education (obtained from ETNIC, the Statistics Service of the Frenchspeaking Community), which we compiled and analysed, confirm and at the same time shed a more nuanced light on this claim. In Table 2 we compare the choices of FL1 between pupils in Brussels and Wallonia, between the different provinces of Wallonia and overall between the 2009-2010 and 2015-2016 school years (the latter being the school year in which data collection for all of the papers in this special issue took place). The most interesting aspects are highlighted in grey.

The first striking fact is that besides Dutch, German and English as an FL1, 17\% of secondary school pupils have no FL at all. In 2015-2016 this equated to 60,640 pupils, $81 \%$ of whom were pursuing vocational education, and $16 \%$ technical. The second noticeable aspect is that the general figures fluctuate because of the variation in Wallonia, as in Brussels there is no choice for the FL1, Dutch being compulsory (95.9\%). If, in Brussels, the percentages change between 2009-2010 and 2015-2016, this is because more pupils have no FL1 (3.1\% to $5.1 \%)$.

Thirdly, over that period of six years there is indeed a clear loss of interest in Wallonia for Dutch as an FL1 (38.6\%) with a mean of $-5.8 \%$ for all secondary years, which coincides with a switch to English as an FL1 
(+6.7\%), chosen by 47\% of the pupils in 2015-2016. When we focus on the figures for the first year of secondary school, the data show that Dutch FL1 decreases over a period of six years from $46.3 \%$ to $37 \%$ (-9.3\%), whereas English progresses from 50.9\% to 59.3\%. Figures cited by Vandeputte $(1979,63)$ indicate that in 1976-1977, 67.5\% of pupils in Wallonia chose Dutch as FL1, 28.2\% English and 4.3\% German (total $N=254,702$ ), which is very different from today's situation. If we do not take into account those pupils having no FL at all, the comparable ratio in 2015-2016 would be $40.3 \%$ for Dutch FL1, 57.8\% for English and 1.9\% for German, confirming the shift has been going on for decades.

Fourthly, FL1 choices differ considerably between provinces in Wallonia. German is a fairly stable but unrepresented FL1 in Wallonia (1.6\%), yet when chosen, it is only in the provinces of Liège $(4.9 \%$ and $4.5 \%$ in 2009-2010 and 2015-2016, respectively) and Luxembourg (3\% and 3.3\%, respectively), which both share a border with Germany (Darquennes 2017). For the choice of Dutch FL1 versus English FL1, another clear pattern emerges: the closer to Brussels, the more Dutch; the further away from Brussels, the more English. In Walloon Brabant, the province with the longest border with Flemish Brabant and situated closest to Brussels, nearly three-quarters of pupils chose Dutch FL1 in 2009-2010 and the figure was still $67.6 \%$ in 2015-2016. At the other end of the spectrum, the province of Luxembourg, in the south-east corner of the country, close to the German and Luxembourg border, has the lowest rate of Dutch FL1 (10.7\%), and the highest of English FL1 (66.6\%). In between, the percentages vary from west to east (Hainaut, Namur, Liège). These differences are hard to explain in terms of proximity of the language border, as Namur has none, but both Hainaut and Liège have borders with provinces in Flanders, and Liège even with the Netherlands (also Dutch-speaking). More detailed figures at school level would be necessary to analyse this phenomenon, but were not available.

The general shift in FL1 from Dutch to English can be explained by the growing importance of English, mainly at international level, as well as its exponential presence in youth culture (music, internet, social media, films and TV). This is despite a very French-oriented cultural framework in Wallonia and a tradition of dubbing instead of using original versions with subtitles (as is the case in Flanders). Moreover, Dutch suffers from low appeal, despite its relevance in the job market and its growing prestige as the language of the demographically and economically dominant majority. Dutch is often perceived as an unattractive, regional and fairly difficult language. This is the case nowadays (De Smet et al. 2019) and has been so for a long time (du Ry 1962; Vandeputte 1979; Mettewie 1998; Lochtman, Lutjeharms, and Kermarrec 2005; Mettewie and Janssens 2007). These negative attitudes towards the language of the 'other' community seem to go along with a polarised political and media system in terms of an 'us' against 'them' discourse, which was particularly evident during the political crisis of 2010-2011 (Mettewie 2015). While some (Deborsu and De Wit 2014, 110-111) have suggested that the recent drop in Dutch FL1 choice is linked to that political context, only circumstantial evidence supports this claim. However, both the French- and the Dutch-speaking communities could have a responsibility and a role to play in creating a more positive image and discourse on the 'other' language and its Community. This would help both French FL1 and Dutch FL1 teachers in their struggle to teach the language of the 'other' community, as already suggested by du Ry in $1962 .^{33}$

To stop this decrease of Dutch as a FL1, the question is regularly raised about making Dutch FL1 compulsory in Wallonia. We will not go into the symbolic pros and cons, or the economic relevance of having all pupils taught sufficient and effective Dutch FL1, or the realistic language outcomes, but will simply point out a practical matter. If Dutch FL1 were to be made compulsory in Wallonia, the need for teachers of Dutch, whose numbers are already drastically low, would dramatically increase. A further challenge lies in the requirement that all FL classes are to be taught at both primary and secondary level by qualified language teachers. Recent figures indicate that $36 \%$ of the teachers teaching Dutch, English or German at primary level are not qualified to do so; this is also the case at secondary level: $30 \%$ for lower secondary school and 26\%, including Spanish FL teachers, at higher secondary level (Les indicateurs de l'enseignement 2018 2019, 57). This means that because there are no language teachers available, anyone with knowledge of the target language will be hired by schools that are in desperate need of teachers. ${ }^{34}$ It also explains why the legislation allows schools to exceed the maximum of 23 pupils per language class, leading to classes with up to 29 learners, and why $35 \%$ of teachers ( $44 \%$ at secondary level) tend to quit their job within five years of starting their career (Delvaux et al. 2013,136), despite tools, guidelines and supporting tandem projects. ${ }^{35}$ This situation does not look likely to improve, as forthcoming legislation, intended to significantly improve the education system (Pacte d'excellence), proposes to start (a) FL learning in Year 1 of primary school in Brussels and Year 3 for all schools in Wallonia with a possibility to 
have Dutch or German as a compulsory FL1 (Mettewie 2020), (b) 'language awareness classes' in preschool and (c) an FL2 starting in the first year of secondary school (instead of the third) ${ }^{36}$. If these measures are implemented, this would mean that even more teachers would be urgently needed. Yet by then it will be more difficult to gain a teaching qualification, with the addition of an extra year of training, without any real improvement in teachers' working conditions, financial incentives or social recognition.

In a nutshell, French-medium schools benefit from significant freedom in terms of the languages they choose to offer as first, second and third FL. There has been a notable drop in popularity for Dutch FL1 in favour of English, though the situation fluctuates throughout the provinces. The French-speaking Community has plans to reinforce FL learning as a whole (Anckaert 2018), but whether these plans will concern the more than 60,000 pupils with no FL at secondary level is unclear. Moreover, the lack of language teachers and the lack of support in general regarding the teachers' working conditions, training and recognition might jeopardise the implementation of these plans for more intensive and effective FL classes in Wallonia, even more so for Dutch FL, due to negative attitudes toward the language.

To conclude this section on FL education, Table 3 gives an overview for the three communities of the options in terms of FL1, FL2 and FL3 in secondary schools. The allotted number of hours has not been included, as this depends on the study programmes, the course combinations and the individual curriculum of the schools.

\section{Bilingual education in Belgium}

Based on the 1963 legislation, no form of bilingual or multilingual education is allowed by law in Belgium (Baetens Beardsmore 1992). Yet, there are six European 'multilingual' schools educating 13,638 children of EU staff ${ }^{37}$ in Belgium, and there some international schools in and around Brussels, such as the German, British and Scandinavian international schools and the Lycée français. Moreover, Belgium would not be the champion of compromises, with a twist of surrealism, if it had not been able to find ways to circumvent the legal constraints in order to legally implement bilingual education, each Community in its own tailor-made way.

In the present paper, we have used bilingual education as an umbrella term for any form of instructed educational programme, at pre-school, primary and secondary level, in which more than one language of instruction is used, regardless of the target population, the pedagogical aims or the status of the language (national majority/minority, low- or high-prestige foreign/ migrant languages).

\section{1. 'Bilingual education' organised by the German-speaking Community}

As indicated above, schools within the German-speaking Community have in principle German, the minority's official language, as the sole language of instruction. At the same time, the legislation allows subjects such as art, music and PE to be taught in French (FL1) at primary school through programmes called 'additional support of the foreign language' during 'content classes'. ${ }^{38}$ At secondary level, $50 \%$ to $65 \%$ (only in the first two years) of the content classes can be taught in French. Teaching content through a target language matches the definition of the European supported type of bilingual education: CLIL (content and language integrated learning, Eurydice 2006). According to the Ministry of Education, this kind of 'intensive' FL programme exists in 8 out of the 9 secondary schools, but figures for the pupils involved were unavailable and were said to fluctuate a lot. ${ }^{39}$ At primary level, none of the 56 schools has currently implemented content teaching in French, but the Ministry of Education intends to encourage schools to start these programmes. It should be noted that there is one exception at pre-school/primary level of a school on the Belgian-German border offering two-way bilingual education in which young French- and German-speaking pupils share most of their classes, while maintaining a higher input in their dominant or first language (60\%) versus their respective target language (40\%) (Bouillon 2018). This is the only example of explicit use of the term 'bilingual education'.

To sum up, bilingual education is not actually mentioned in the legislation and yet is allowed at all educational levels within the German-speaking Community, through additional FL support projects at primary school and intensive content classes in the TL (50\% to 65\%) at secondary school, and a two-way bilingual pilot project ( $40 \%$ in the TL). This is reminiscent of Magritte's surrealist painting of a pipe with 
the text 'this is not a pipe', as the German-speaking Community allows, supports and in the future intends to promote programmes having all the features of bilingual tracks, though not presenting them as such. Without challenging the language policy discourse on maintaining and supporting German as a minority language, the German-speaking Community thus leaves it to the discretion of the educational stakeholders (schools and parents) whether to organise bilingual programmes in addition to compulsory intensive FL education. The question remains, however, as to the reason for pupils', parents' and educators' low response to this opportunity.

\section{2. 'Bilingual education' organised by the Dutch-speaking Community (Flanders and Brussels)}

In the Dutch-speaking area, there is a similar reluctance to introduce languages other than Dutch as the language of instruction, generally at pre-school/primary level, but also in secondary education. In the nineteenth and twentieth centuries the Flemish nationalist movement fought for education in the language of the majority of the people instead of in French, which was regarded as the language of the upper classes in Flanders, Brussels and Wallonia. Dutch was only slowly introduced as an instruction language in Staterun schools, starting in 1883, and was reluctantly introduced from 1910 on in the more numerous Catholic schools (Swing 1988; Van der Sijs and Willemyns 2009).

The University of Ghent was the first to offer full degree courses in Dutch instead of French, but not until 1930. The first attempts to introduce a form of bilingual (Dutch/French) education in Brussels in the early twentieth century were aimed at supporting Dutch-speaking children to attain a sufficient level in French to enable them to pursue their education. However, these so-called transmutation classes were not successful and were seen as an attempt to 'frenchify' even more the Dutch-speaking population of the capital (Treffers-Daller 2002; Van de Craen 2002). Despite the socio-political, economic and cultural emancipation of Flanders in the second half of the twentieth century, French continued to be perceived as the language of social oppression. In their analysis of press debates in the early twenty-first century, Bollen and Baten (2010) still found evidence of the fear of a new Frenchification of Dutch-medium education and concluded that in 2006 Flanders was still profoundly divided on the issue of bilingual education (430). It is therefore not surprising that intense political debate and evaluation of two cohorts in nine pilot projects (Strobbe and Sercu 2011) were necessary to eventually authorise CLIL-type bilingual programmes in Dutch-medium secondary schools in $2014-2015{ }^{40}$ The model of bilingual education that was aimed at was clearly that of an additive bilingualism (with high-prestige languages) organised for the Dutch-speaking majority population, whatever sociolinguistic diversity there might be in the classroom.

CLIL in Flanders is (a) governed by strict regulations, involving extensive application and monitoring procedures ${ }^{41}$ and (b) restricted to secondary education for a maximum of $20 \%$ of the curriculum (in addition to regular FL classes) in order to ensure instruction of and in Dutch and with the guarantee that a full Dutch track is still available. Since 2014, the number of schools organising a bilingual track keeps growing, as illustrated in Table 4. Reliable figures on the total numbers of pupils involved in CLIL appear to be currently unavailable.

Every year about 20 schools initiate CLIL programmes, which has led to a total number of 124 schools in just six years' time. Figures indicate that the highest number of schools is in West and East Flanders, whereas the lowest is in Brussels and around the capital region (Flemish Brabant). The available list of schools ${ }^{42}$ indicates that CLIL is organised at all levels of secondary school and in all the general tracks leading to higher education (ASO), as well as in at least a third of the schools offering vocational, technical or artistic education (BSO, TSO, KSO).

The target languages legally authorised for CLIL in Dutch-medium schools are French and German, the other two national languages, as well as English. Schools are allowed to offer more than one CLIL language. Although the latest figures available are unclear about the number of subjects and the classes in which these different target languages are used, English is clearly dominant, as it is implemented (alone or in combination) in 100 schools out of 124 (81\%). Nevertheless, French is also popular as a CLIL language and is offered by 69 schools (56\%), while German is only available in 6 schools (5\%), mainly in combination with English and/or French and only in the general track, with no clear geographical pattern (i.e. not close to the German border). 
As for the subjects taught through CLIL, there are no legal constraints, and these range from biology and economics to hairdressing and religion, though they are limited to one or two per

pupil, per week (cf. max. 20\% next to regular FL classes on the basis of a weekly timetable of 32-36 h). Interestingly, a 2017 report noted that French appeared to be used more frequently as a CLIL language in vocational education, which is attributed to its relevance for better job prospects, but also to increase French learning motivation (Vlaamse Onderwijsinspectie 2017b, 28).

In sum, although CLIL has only very recently been authorised in Dutch-medium schools in Flanders and Brussels because of the sensitive socio-political history of education, it seems clear that once it has been greenlighted, schools are eager to innovate through CLIL. Because of Flanders' priority regarding proficiency in the official language, Dutch, CLIL is only allowed at secondary level and for a circumscribed number of hours a week. English and French are clearly the most popular target languages and are used at all levels of secondary education and in all tracks. Together with the European trend to promote CLIL, the efforts of many practitioners and members of the academic community - through pilot projects in Flanders and in Brussels ${ }^{43}$ and knowledge mobilisation among politicians and the broader public - have made it possible to overcome the resistance to bilingual forms of education inherited from the past and have led to growing success in Dutch-medium schools.

\section{Brussels)}

4.3. 'Bilingual education' organised by the French-speaking Community (Wallonia and

Unlike the situation in Flanders, bilingual education has been implemented in French-medium schools for more than 20 years. It started with a number of pilot projects (Blondin 2003; Chopey- Paquet 2007) in the early 1990s and was officially authorised at pre-school/primary level by a decree of the French-speaking Community in $1998 .{ }^{44}$ It was then fine-tuned in a series of decrees and circulars, ${ }^{45}$ which also extended it to secondary education. In the legislation, the type of bilingual education planned is called 'immersion', a term also used by the media and many parents and children. Professionals mostly use the term CLIL (or the French acronym EMILE $^{46}$ ), as it shares the characteristics of the European CLIL programmes (Eurydice 2006; Maljers, Marsh, and Wolff 2007) and embeds the projects in a broader European perspective. For the sake of readability and consistency, we will henceforth use CLIL rather than 'immersion'.

To circumvent the language laws regarding the language of instruction, CLIL in French-medium education has to be presented as a specific pedagogical project, supported by all the school's stakeholders (school head, teachers, staff members, parents, etc.). Once permission has been granted, the project has to be reported on every three years. Like the CLIL projects in Dutch-medium schools, these programmes are meant for all children involved in French-medium education, regardless of their home language(s).

Contrary to Flanders, there were no obstacles to authorising the introduction of CLIL from preschool until the end of secondary school, as the language of instruction (i.e. French) was not perceived as being under threat within the Belgian (historical) context. Target language(s), as well as subjects and number of hours allotted to CLIL are regulated, yet, at the same time, are extremely flexible, as the aim of the legislation is that bilingual programmes should account for the local context and expectations. In all cases, the official language of instruction is, as legally required, French, supplemented by a CLIL language, which can be English, German or Dutch. Note that the decree also allows for Belgian French Sign Language (BFSL) to be taught in bilingual classrooms. Until now, only one school offers bilingual schooling in BFSL and spoken French (Meurant and Ghesquiere 2018).

Since 1998, the demand (mainly from parents) for CLIL classes has been significant and has led to a steadily growing number of pre-primary, primary and secondary schools following suit, as can be seen in Table 5 . The latest figures we were able to obtain, validated by the Statistics Service of the Ministry of Education (ETIC), indicate that in 2015-2016, 289 schools organised CLIL (169 at preschool/primary and 120 at secondary level), with a total of 29,041 pupils attending CLIL classes. Even though the figures seem to fluctuate a little over the years (32,182 pupils in 2013-2014 compared with 30,430 pupils in 2017-2018), we can conclude that about 30,000 pupils are involved in CLIL tracks. This may seem a large number, but in 2015-2016 it represented only 3.4\% of the total school population in French-medium schools $1.4 \%$ for pre-school, $4.1 \%$ at primary and $3.6 \%$ at secondary level). 
As Table 6 shows, the different starting moments and number of CLIL hours/week vary between $28 \%$ and $75 \%$ at pre-school/primary level or $25 \%$ to $40 \%$ at secondary level. Although schools regularly report drop-outs, ${ }^{47}$ these percentages of CLIL classes imply that pupils can have a minimum of four years of CLIL and a maximum of 11 years by the end of their education, with different degrees of exposure. Different systems exist at primary level, as schools can opt to start with a large number of hours in the target language, decreasing over time in favour of French (75\%-50\%-25\%), or vice versa, or for an evenly balanced spread of French and the CLIL language. This excludes classes of religion, ethics or citizenship, which are to be given in the only official language of instruction (French); any other subject can be taught through the target language, including PE. This also means that primary schools can choose to start teaching reading and writing in French or in the target language.

As mentioned earlier, schools can choose from the three target languages and are even allowed to organise CLIL programmes in two of them. To ensure consistency, pupils are nevertheless restricted to one language track for at least two years. In the first two years of secondary school, the CLIL language must be the pupil's first FL; later it can be their second FL. With regard to the distribution of schools according to the CLIL target language and the province in which they are located (see Table 7), a few points are noteworthy.

Firstly, there are more CLIL programmes in pre- and primary school than at secondary level in Frenchspeaking Belgium. Secondly, the geographical spread is unbalanced across provinces and might tentatively be explained by a greater economic need for multilingual skills in regions with high unemployment and/or common borders with Dutch-speaking Flanders. Thirdly, German as a CLIL language is, as with the choice of FL, more common in the eastern and south-eastern part of Belgium, close to the German and Luxembourg borders. Finally, unlike the FL choices, Dutch is the target language in CLIL programmes more often than English and this does not follow the geographical pattern of the FL choice distribution. This higher frequency of Dutch is confirmed by the number of pupils in CLIL programmes, as detailed in Table 8, even though this number tends to decrease at secondary level.

It should be noted that all the internal assessments of CLIL subjects are in the target languages, but pupils have to take the final, externally developed exams in French, as they are expected to reach the same level of knowledge and mastery of both content and French language as pupils in the regular tracks, which is regularly mentioned as a source of discomfort or stress. Recent research indicates that this should not be a cause of concern (Szmalec et al. in preparation). At the same time, there is no official and formal recognition of the higher level of acquisition of the target language(s), which is often seen by pupils and teachers as unfair, given the extra effort they put in across their CLIL curriculum.

Finally, we would like to point out that, although CLIL in French-medium education receives limited support from the Ministry of Education (websites with good practices and tools, central advisory board, etc.), the freedom that schools have within the legal framework is an ingredient of CLIL's success, as it fits in with the socio-cultural environment and expectations of the school community. Yet at the same time this freedom is a stumbling block, as it makes it very difficult to issue guidelines, identify milestones and develop courses, not to mention devise and publish appropriate teaching material and provide proper support and in-service training for teachers.

Consequently, there is still much to be done to ensure the long-term success of CLIL in French- speaking Belgium.

\section{Conclusion}

The intricate institutional make-up of Belgium, together with a number of historic, socio-economic and political factors, has shaped its educational landscape. Based on a strict legal framework concerning language instruction, the three Language Communities (Dutch, French and German) that are separately in charge of education have each made their own choices regarding foreign language and bilingual education, resulting in a patchwork of options for pupils and their parents. Foreign language and bilingual education in Belgium can therefore be described as tailor-made, reflecting each Community's socio-political priorities, baring traces of their history. So, for instance, the attachment of the German-speaking community to German as the sole official language of instruction can be linked to their minority status within the Frenchspeaking Walloon Region and their history of being handed back and forth between Germany and Belgium. 
Similarly, the reluctance of the Dutch-speaking Community to introduce bilingual education can be related to its apprehensiveness regarding a possible re-frenchification of education as was the case in the nineteenth and early twentieth century, whereas in the French-speaking Community foreign languages as languages of instruction have not been seen as a possible threat but rather as assets in order to respond to a challenging economic context since the 1960s.

Broadly speaking, the current situation can be summarised as follows. To respond to its minority context, language education in the German-speaking Community is characterised by a strong focus on FL learning from preschool through secondary education. Their intensive approach includes the possibility to teach classes in French, thus bearing features of CLIL, though it is never named as such. However, it remains unclear how successful these intensive courses really are. In the Dutch-speaking Community, CLIL has been allowed since 2014 with a steadily increasing number of participating schools spanning the full range of education tracks, from general to vocational. However, CLIL is only allowed at secondary level and for a limited percentage of teaching hours. The most popular target language is English, followed by French, whereas in FL education French is the compulsory first FL (primary and secondary school). This is not the case in the French-speaking Community in Wallonia, where the first FL can freely be chosen, which has led to a shift from Dutch to English as the most popular FL. In CLIL, which has been introduced in 1998 and developed from preschool through secondary school, the most popular target language remains Dutch. The varying intensity of FL classes across Language Communities and Regions is even more obvious in the Brussels Capital Region and the so-called municipalities with facilities, and it clearly illustrates how the institutional jigsaw puzzle has impacted (foreign language) education.

The complex situation described above brings about a series of challenges, including the following. First, both in FL classes and bilingual education, only high-status languages are represented, meaning hardly any space is reserved for minority (read migrant) languages. This in stark contrast to the highly linguistically diverse composition of most Belgian towns and cities. Next, as expectations for the high-status languages are high, the Language Communities intend to start FL learning at a younger age, which is a positive development but will undoubtedly result in an even greater shortage of language teachers. Finally, there is a striking contrast between the high perceived attractiveness of English as a global language and, whenever possible, as the preferred FL, compared to the often far less favourable attitudes towards the languages of the 'other' communities in Belgium, resulting in challenging circumstances for teachers of these languages.

In sum, language(s) of instruction and foreign language education are highly symbolic and therefore enshrined in stringent legislation, but pragmatism has called for creativity in designing and developing an array of custom-made educational programmes both for FLs and CLIL in a small country such as Belgium. This has led to paradoxical situations where bilingual education as such is, strictly speaking, not allowed, yet it is implemented and even promoted. As such, one might argue that foreign language and bilingual education in Belgium is yet another example of the country's tradition of surrealism.

\section{Notes}

1. Krijgt Brussel meertalige scholen? De Standaard, 26-03-2019; Un projet d'école multilingue à Bruxelles. Le Soir, 26- 032019.

2. Total population of Belgium on 1 January 2018 was 11,376,070. Source: http://statbel.fgov.be/ [retrieved 10-04- 2019].

3. https://www.belgium.be/en/about_belgium/government/regions/competence/ [retrieved 10-04-2019].

4. https://www.belgium.be/en/about_belgium/government/communities [retrieved 10-04-2019].

5. This area belonged to Germany, but was added to Belgium in 1919 as compensation for its losses during World War I.

6. https://www.belgium.be/sites/default/files/belgium_at_a_glance_en_lowres.pdf [retrieved 10-04-2019].

7. http://www.vocabulairepolitique.be/commune-a-facilites/ [retrieved 10-04-2019].

8. Law of 24 July 1961, art. 3 '[...] le recensement général de la population de 1961 ne comporte aucune question relative à l'emploi des langues; les effets du recensement linguistique, effectué le 31 décembre 1947, sont prolongés jusqu'à ce qu'une loi y mette fin'.

9. 18 AVRIL 1898. - LOI relative à l'emploi de la langue flamande dans les publications officielles (Loi d'égalité - abrogée par L 1961-05-31/30, art. 9).

10. http://www.deredactie.be/cm/vrtnieuws/politiek/1.1035144 [retrieved 10-04-2019].

11. http://www.youtube.com/watch?v=i0F8qf_Lqc8\&NR=1\&feature=endscreen [retrieved 10-04-2019].

12. http://www.ejustice.just.fgov.be/cgi_loi/change_lg.pl?language $=$ fr\&la=F\&cn=1963073031\&table_name=loi [retrieved 10-04-2019].

13. https://www.vgc.be/sites/vgc/files/2019-06/1819_website_evolutie_NOB_samengevoegd.pdf [retrieved 25-11- 2019].

14. Art. 6 of the 1963 law, http://www.ejustice.just.fgov.be/eli/loi/1963/07/30/1963073006/justel [retrieved 10-042019]. 
15. This is the case for 11 French-medium schools within the Flemish area, https://www.onderwijskiezer.be/v2/basis/ basis_zoek.php?submit=zoeken [retrieved 10-04-2019].

16. http://www.taalwetwijzer.be/onderwijs/de_faciliteitengemeenten.html [retrieved 10-04-2019].

17. Art. 17-18 of the 1963 law stipulates schools should make sure parents comply with the language legislation, with room for small exceptions, which are controlled by the language inspection, http://www.ejustice.just.fgov.be/eli/loi/1963/07/30/1963073006/justel [retrieved 10-04-2019].

18. https://www.g-o.be/samen-leren-samenleven-ons-ppgo/ and http://www.enseignement.be/index.php?page= 23725 [retrieved 18-12-2019].

19. https://www.ostbelgienbildung.be/desktopdefault.aspx/tabid-2201/ [retrieved 19-08-2019].

20. http://www.ostbelgienbildung.be/desktopdefault.aspx/tabid-2403/4386_read-31707/ [retrieved 10-04-2019].

21. Decreet Basisonderwijs 17 April 1997, https://data-onderwijs.vlaanderen.be/edulex/document.aspx?docid= 12254\#1022130 [retrieved 10-04-2019].

22. https://www.onderwijskiezer.be/v2/basis/ [retrieved 10-04-2019].

23. https://www.vgc.be/sites/vgc/files/2019-06/1819_website_evolutie_NOB_samengevoegd.pdf [retrieved 25-11- 2019]

24. https://www.standaard.be/cnt/dmf20191211_04761485 and https://www.vrt.be/vrtnws/fr/2019/12/10/1_ apprentissage-du-francais-en-flandre-est-il-menace/ [retrieved 18/12/2019].

25. https://www.coe.int/en/web/common-european-framework-reference-languages/level-descriptions [retrieved10/04/2020].

26. https://onderwijs.vlaanderen.be/nl/taalkennis, https://data-onderwijs.vlaanderen.be/edulex/document.aspx? docid=14173 [retrieved 10-04-2019].

27. https://www.klasse.be/134834/leraren-basisonderwijs-frans-spreken/ [retrieved 10-04-2019].

28. https://www.vrt.be/vrtnws/nl/2020/01/15/studenten-kennen-onvoldoende-frans-uhasselt-voert-een-nieuw-vak/ [retrieved 06-01-2020].

29. Décret Bourgeois: 'L'étude des langues modernes dans la région de langue française', 21 February 1980, http:// www.pfwb.be/le-travail-du-parlement/doc-et-pub/documents-parlementaires-et-decrets/documents/000048659 [retrieved 10-04-2019].

30. Rapport de la Commission de l'Enseignement, 7 December 1976, http://www.pfwb.be/le-travail-du-parlement/ doc-et Art. 69 Decret 13 juillet 1998 in https://www.gallilex.cfwb.be/fr/leg_res_02.php?ncda=22229\&referant=l01 [retrieved 25-11-2019].

31. Decret 13 juillet 1998 in https://www.gallilex.cfwb.be/fr/leg_res_02.php?ncda=22229\&referant=l01 [retrieved 25-112019].

32. 'Le jour où avec vos enfants et pour eux, vous aurez réussi à démêler cet obscur enchevêtrement où se croisent tant d'ignorance, de demi-vérités, de préjugés, de réflexes passionnels ... vous aurez singulièrement facilité la tâche de leur professeur de néerlandais' (du Ry 1962, 47)

33. Cartoon illustrating anybody present in a school is considered a potential teacher https://www.enseignons.be/ 2018/03/03/une-penurie-sans-fin/ [retrieved 10-04-2019].

34. http://www.ecoles.cfwb.be/argattidegamond/Espace\%20professeurs/guide_jeune_ens.pdf and http://www. ecoles.cfwb.be/argattidegamond/Espace\%20professeurs/guide_jeune_ens.pdf [retrieved 10-04-2019].

35. Pacte d'excellence, Avis $\mathrm{n}^{\circ} 3$, June 2017, p. 48, http://www.enseignement.be/ [retrieved 10-04-2019].

36. In 2018-2019, some 13,638 pupils attended the Schola Europea in Brussels and near Antwerp. Source: https:// www.eursc.eu/en/Office/reports-statistics [retrieved 10-04-2019].

37. In German "mit erhöhter Förderung der Fremdsprache' and 'Sachunterricht'

38. E-mail correspondence with Corina Senster, school inspector at the Ministerium der Deutschsprachigen Gemeinschaft (35 May 2018).

39. https://data-onderwijs.vlaanderen.be/edulex/document.aspx?docid=14721 [retrieved 15-04-2019].

40. https://onderwijs.vlaanderen.be/nl/clil-content-and-language-integrated-learning\#Voorwaarden-voor-clil [retrieved 25-11-2019].

41. https://onderwijs.vlaanderen.be/nl/clil-content-and-language-integrated-learning\#Bottom [retrieved 19-08- 2019]

42. Stimob (Stimulerend meertalig onderwijs Brussel), e.g. Van de Craen et al. (2007).

43. https://www.gallilex.cfwb.be/fr/leg_res_02.php?ncda=22229\&referant=101 [retrieved 25-11-2019].

44. 2003 (https://www.gallilex.cfwb.be/document/pdf/27862_002.pdf), 2007 (https://www.gallilex.cfwb.be/document/ pdf/32365_003.pdf), Circulaire n4112 (24/08/2012), Circulaire n5796 (30/06/2016), decree project 780 (March 2019).

45. EMILE: Enseignement d'une matière par intégration d'une langue étrangère; this acronym is a nod to Rousseau's work on pedagogy Emile ou De l'éducation (1762).

46. Personal communication with the principal of a CLIL school, May 2018

\section{Acknowledgements}

We would like to thank Elsa Albarello (Statistics Service of the Ministry of Education) and Catherine Lefevre (ETNIC, Féd- ération Wallonie-Bruxelles) for their invaluable cooperation and willingness to share the statistical data available. We are also grateful to Wim De Grieve and Dirk Delabastita for their useful comments and suggestions.

\section{Notes on contributors}

Laurence Mettewie is professor of Dutch language and linguistics at the Université de Namur (Belgium). Her research focuses on societal aspects of multilingualism, multilingual education and emotional and socio-affective factors involved in SLA. 
Luk Van Mensel is a postdoctoral researcher at the NaLTT Institute (Université de Namur, Belgium). He has published on a variety of subjects in SLA and sociolinguistics, and is the coordinator of the research project 'Assessing Content and Language Integrated Learning (CLIL): Linguistic, cognitive and educational perspectives'.

CONTACT laurence.mettewie@unamur.be; luk.vanmensel@unamur.be

\section{References}

Anckaert, Ph. 2018. “Améliorer l'enseignement des langues modernes en FWB.” Enseigner 141: 23-25.

Baetens Beardsmore, H. 1992. "Bilingual Education.” In Cultural Diversity and the Schools: Vol I. Education for Cultural Diversity: Convergence and Divergence, edited by J. Lynch, C. Modgil, and S. Modgil, 273-283. Washington, DC: Falmer Press.

Blondin, C. 2003. “L'immersion linguistique dans l'enseignement fondamental en communauté française de Belgique : l'état de la question." Journal de l'immersion 25 (2): 19-31.

Boemer, M., and J. Darquennes. 2015. "Language Conflict in the Educational Realm: Eupen-Malmedy in the Interbellum Period (1920-1940)." In Past, Present and Future of a Language Border: Germanic-Romance Encounters in the Low Countries, edited by C. Peersman, G. Rutten, and R. Vosters, 207-232 (Language and Social Processes; Vol. 1). Berlin: de Gruyter.

Bollen, K., and K. Baten. 2010. “Bilingual Education in Flanders: Policy and Press Debate (1999-2006).” The Modern Language Journal 94 (3): 412-433.

Bouillon, H. 2018. “L'enseignement en Communauté germanophone de Belgique: histoire, institutions et enjeux actuels.” Synergies Pays germanophones 11: 153-169.

Ceuleers, E. 2008. “Language and Identity in Brussels.” Unpublished PhD diss., VUB.

Chopey-Paquet, M. 2007. "Belgium (French-Speaking).” In Windows on CLIL. Content and Language Integrated Learning in the European Spotlight, edited by A. Maljers, D. Marsh, and D. Wolff, 28-32. Graz: European Centre for Modern Languages.

Darquennes, J. 2013. "Deutsch als Muttersprache in Belgien: Forschungsstand und Forschungsperspektiven.” In Vielfalt, Variation und Stellung der deutschen Sprache, edited by K. Schneider-Wiejowski, B. Kellermeier-Rehbein, and J. Haselhuber, 349-368. Berlin: De Gruyter.

Darquennes, J. 2017. “Die Lage des Deutschen als Fremdsprache im Primar- und Sekundarunterricht im belgischen Teilder Großregion Eine Bestandsaufnahme.” Muttersprache 127 (1-2): 30-41.

Deborsu, Ch, and A. De Wit. 2014. Dag, bonjour! Waarom Vlamingen en Walen gedoemd zijn om te scheiden (maar wij misschien niet). Gent: Borgerhoff \& Lamberigts.

Declercq, K., K. Denies, and R. Janssen. 2012. Vlaamse vreemdetalenkennis in Europees perspectief. Balans van het ESLC- onderzoek. Brussels: Vlaams Ministerie van Onderwijs en Vorming.

Delvaux, B., P. Desmarez, V. Dupriez, S. Lothaire, and M. Veinstein. 2013. "Les enseignants débutants en Belgique francophone : trajectoires, conditions d'emploi et positions sur le marché du travail.” Les cahiers de recherche du Girsef 92: 1-157.

Deprez, K., Y. Persoons, M. Struelens, and A. Wijnants. 1982. “Anderstaligen in het Nederlandstalig basisonderwijs in Brussel: wie en waarom?" Taal en Sociale Integratie 6: 231-263.

De Smet, A., L. Mettewie, Ph Hiligsmann, B. Galand, and L. Van Mensel. 2019. “Does CLIL Shape Language Attitudes and Motivation? Interactions with Target Languages and Instruction Levels.” International Journal of Bilingual Education and Bilingualism. doi:10.1080/13670050.2019.1671308.

De Wilde, V., M. Brysbaert, and J. Eyckmans. 2020. "Learning English Through Out-of-School Exposure: Which Levels of Language Proficiency are Attained and Which Types of Input are Important?" Bilingualism: Language and Cognition 23 (1): 171-185.

du Ry, J.-P. 1962. “En marge du cours de néerlandais: Leur langue: Soit! Mais, eux! ...." La Nouvelle Revue Pédagogique 1: 44-49.

Eurydice. 2006. Content and language integrated learning (CLIL) at school in Europe. http://bookshop.europa.eu/en/ content-andlanguage-integrated-learning-clic-at-school-in-europe-pbNCX106001/.

Goossens, J., and P. Cannoot. 2015. “Belgian Federalism After the Sixth State Reform.” Perspectives on Federalism 7 (2): $29-55$.

Greten, V. 2008. Unterricht und Ausbildung in der Deutschsprachigen Gemeinschaft Belgiens. Eupen: Ministerium der Deutschsprachigen Gemeinschaft Belgiens Schriftenreihe: Band 3.

Housen, A., S. Janssens, and M. Pierrard. 2003. "Le français face à l’anglais dans les écoles secondaires en Flandre.” Français et Société 15. Louvain-la-Neuve: Duculot.

Janssens, R. 2007. “Het Nederlands in het Brusselse onderwijslandschap.” Neerlandica Extra Muros 45 (2): 21-33.

Janssens, R. 2009. Onderzoek naar de capaciteit van het Nederlandstalig basisonderwijs in het Brussels Hoofdstedelijk Gewest. Research report. Brussels: BRIO.

Janssens, R. 2013. “The Linguistic Landscape as a Political Arena: The Case of the Brussels Periphery in Belgium.” In Linguistic Landscapes, Multilingualism and Social Change, edited by C. Hélot, M. Barni, R. Janssens, and C. Bagna, 39-51. Frankfurt: Peter Lang.

Janssens, R., D. Carlier, and P. Van de Craen. 2009. “Education in Brussels / Het onderwijs in Brussel / L'enseignement à Bruxelles. Synopsis CFB 5." Brussels Studies, 1-19. 
Jaspers, J. 2015. “Modelling Linguistic Diversity at School: The Excluding Impact of Inclusive Multilingualism." Language Policy 14 (2): 109-129.

Leemans, L. 2018. "Leraren moeten meer Frans spreken tijdens de les." Klasse, June. https://www.klasse.be/134834/ lerarenbasisonderwijs-frans-spreken/.

Les indicateurs de l'enseignement 2018. 2019. "Ministère de la Fédération Wallonie-Bruxelles." http://www.enseignement.be/index.php?page=28273\&navi=2264.

Lochtman, K., M. Lutjeharms, G. Kermarrec, et al. 2005. “Langues étrangères à Bruxelles: recherche sur les attitudes d'étudiants Bruxellois des écoles d'ingénieur commercial ULB et VUB." In Language, Attitudes and Education in Multilingual Cities, edited by Witte et al. 211-233. Brussels: Koninklijke Vlaamse Academie van België voor Wetenschappen en Kunst.

Maljers, A., D. Marsh, and D. Wolff, eds. 2007. Windows on CLIL. Content and Language Integrated Learning in the European Spotlight. Graz: European Centre for Modern Languages.

McRae, K. D. 1986. Conflict and Compromise in Multilingual Societies. Belgium. Waterloo: Wilfried Laurier Press.

Mettewie, L. 1998. "Remmingen bij Franstaligen om het Nederlands te leren of de plaats van het Nederlands in hun waardensysteem." In Racisme: een element in het conflict tussen Franstaligen en Vlamingen / Racisme: un élement dans le conflit entre francophones et Flamands, edited by A. Morelli, L. Dierickx, and D. Lesage, 144-145. Berchem/Bruxelles: EPO/Labor.

Mettewie, L. 2007. “Elèves non-néerlandophones dans l’enseignement néerlandophone à Bruxelles : analyse des répercussions éducatives de la traversée de la frontière linguistique." In L'éducation au-delà des frontières, Apprentissage précoce du néerlandais, apprentissage précoce en néerlandais dans la zone frontalière franco-belge, edited by L. Puren and S. Babault, 141-178. Paris: L'Harmattan.

Mettewie, L. 2015. “Apprendre la langue de «l'Autre » en Belgique : la dimension affective comme frein à l'apprentissage." Le Langage et l'Homme 50 (2): 23-42.

Mettewie, L. 2020. “Wordt Nederlands een verplicht vak in Wallonië?” Neerlandia 124 (1): 30-31.

Mettewie, L., and R. Janssens. 2007. “Language Use and Language Attitudes in Brussels.” In Multilingualism in European Bilingual Contexts. Language Use and Attitudes, edited by D. Lasagabaster and Á Huguet, 117-143. Clevedon: Multilingual Matters.

Meurant, L., and M. Ghesquiere. 2018. École et surdité: Une expérience d'enseignement bilingue et inclusif. Namur: Presses universitaires de Namur.

Mnookin, R., and A. Verbeke. 2009. "Persistent Nonviolent Conflict with no Reconciliation: The Flemish and Walloons in Belgium." Law and Contemporary Problems 72 (2): 151-186.

Morelli, A., and L. Mettewie. 1994. "Il Socialismo belga e "cette plaisanterie de parler ici flamand"." Socialismo e nazione 1: 64-79.

Peiling Frans in het basisonderwijs. 2018. "Brussels: Vlaamse Ministerie voor Onderwijs en Vorming." http://eindtermen. vlaanderen.be/peilingen/basisonderwijs/peilingen/files/frans/Peiling_Frans2018_digitaal.pdf.

Peters, E. 2018. “The Effect of out-of-Class Exposure to English Language Media on Learners' Vocabulary Knowledge.” ITL International Journal of Applied Linguistics 169 (1): 142-168.

Potvin, M., A. Morelli, and L. Mettewie. 2004. “Du racisme dans les rapports entre groupes au Canada et en Belgique." Journal of Canadian Ethnic Studies 36 (3): 25-60.

Sinardet, D. 2008. "Vlaamse en Franstalige media over Franstaligen en Vlamingen: wederzijdse representaties van de "andere" in politieke debatprogramma's." In Media, cultuur, identiteit: actueel onderzoek naar media en maatschappij, edited by H. Van den Bulck and A. Dhoest, 51-69. Gent: Academia Press.

Strobbe, L., and L. Sercu. 2011. Rapport CLIL proeftuinen. https://www.vlaanderen.be/publicaties/wetenschappelijke- begeleidingen-evaluatie-van-de-clil-projecten-in-het-secundair-onderwijs-in-vlaanderen

Swing, E. S. 1988. "Bilingualism and Linguistic Separatism in Belgian Schools.” In International Handbook of Bilingualism and Bilingual Education, edited by C. B. Paulston, 63-83. New York: Greenwood Press.

Treffers-Daller, J. 2002. "Language use and Language Contact in Brussels.” Journal of Multilingual and Multicultural Development 23 (1\&2): 50-64.

Van de Craen, P. 2002. “Belgium.” In Modern Languages Across the Curriculum, edited by M. Grenfell, 69-77. London: Routledge.

Van de Craen, P., K. Lochtman, E. Ceuleers, K. Mondt, and L. Allain. 2007. “An Interdisciplinary Approach to CLIL Learning in Primary Schools in Brussels." In Empirical Perspectives on CLIL Classroom Discourse, edited by C. Dalton

Puffer and U. Smit, 253-274. Frankfurt am Main: Peter Lang.

Vandeputte, 0. 1979. “L'enseignement du néerlandais en Wallonie et du français en Flandre." Septentrion 8: 57-66.

Van der Sijs, N., and R. Willemyns. 2009. Het verhaal van het Nederlands: een geschiedenis van twaalf eeuwen. Amsterdam: Uitgeverij Bert Bakker.

Vlaamse Onderwijsinspectie. 2017a. Onderwijsspiegel 2017, jaarlijks rapport van de onderwijsinspectie. Brussels: Vlaamse Ministerie voor Onderwijs en Vorming.

Vlaamse Onderwijsinspectie. 2017b. Twee jaar CLIL in het Vlaams secundair onderwijs: een evaluatie. Brussels: Vlaamse Ministerie voor Onderwijs en Vorming.

Vogl, U., and M. Hüning. 2010. “One Nation, One Language? The Case of Belgium.” Dutch Crossing 34 (3): 228-247. 
Willemyns, R. 2003. Het verhaal van het Vlaams. De geschiedenis van het Nederlands in de zuidelijke Nederlanden. Antwerpen: Standaard Uitgeverij.

Witte, E., and H. Van Velthoven. 2010. Strijden om taal. De Belgische taalkwestie in historisch perspectief. Kapellen: Uitgeverij Pelckmans. 
Table 1: Authorized language of instruction and foreign languages for each Language Community and Region in Belgium.

\begin{tabular}{|c|c|c|c|}
\hline $\begin{array}{l}\text { Community in } \\
\text { charge }\end{array}$ & $\begin{array}{l}\text { Dutch-speaking } \\
\text { Com. }\end{array}$ & $\begin{array}{c}\text { French-speaking } \\
\text { Com. }\end{array}$ & $\begin{array}{c}\text { German-speaking } \\
\text { Com. }\end{array}$ \\
\hline Where? & $\begin{array}{l}\text { Flemish Region \& } \\
\text { Brussels Cap. Reg. }\end{array}$ & $\begin{array}{l}\text { Walloon Region \& } \\
\text { Brussels Cap. Reg. }\end{array}$ & $\begin{array}{l}\text { German area, within } \\
\text { Walloon Region }\end{array}$ \\
\hline $\begin{array}{l}\text { Language of } \\
\text { instruction* }\end{array}$ & Dutch & French & German \\
\hline $\begin{array}{l}1^{\text {st 'foreign' }} \\
\text { language - only } \\
\text { during FLL classes }\end{array}$ & French & $\begin{array}{l}\text { Dutch** or German } \\
\text { or English }\end{array}$ & French \\
\hline $\begin{array}{l}\text { Other foreign } \\
\text { language(s) }\end{array}$ & $\begin{array}{c}\text { English } \\
\text { German / Spanish }\end{array}$ & $\begin{array}{c}\text { Dutch / English / } \\
\text { German / Spanish / } \\
\text { Italian / Russian }\end{array}$ & $\begin{array}{c}\text { English / } \\
\text { Dutch / Spanish }\end{array}$ \\
\hline
\end{tabular}

* except for municipalities with 'facilities'

** compulsory in Brussels and municipalities with 'facilities' 
Table 2: Distribution of the FL1 in French-medium secondary schools, comparison 2009-10 vs. 2015-16.

\begin{tabular}{|c|c|c|c|c|c|c|c|c|c|c|c|c|c|c|c|}
\hline \multirow[t]{2}{*}{$\begin{array}{l}\text { Secondary } \\
\text { Education }\end{array}$} & & \multicolumn{2}{|l|}{ Tot $N$} & \multirow{2}{*}{$\begin{array}{r}\text { Dutch } \\
09-10 \\
\end{array}$} & \multirow{2}{*}{$\begin{array}{r}\% \\
15-16 \\
\end{array}$} & \multirow[b]{2}{*}{$\neq$} & \multirow{2}{*}{$\begin{array}{r}\text { German } \\
09-10 \\
\end{array}$} & \multirow{2}{*}{$\begin{array}{r}\% \\
15-16 \\
\end{array}$} & \multirow[b]{2}{*}{$\neq$} & \multirow{2}{*}{$\begin{array}{r}\text { English } \\
09-10 \\
\end{array}$} & \multirow{2}{*}{$\begin{array}{r}\% \\
15-16 \\
\end{array}$} & \multirow[b]{2}{*}{$\neq$} & \multirow{2}{*}{$\begin{array}{r}\text { No FL1 } \\
09-10 \\
\end{array}$} & \multirow{2}{*}{$\begin{array}{r}\% \\
15-16 \\
\end{array}$} & \multirow[b]{2}{*}{$\neq$} \\
\hline & & 09-10 & $15-16$ & & & & & & & & & & & & \\
\hline \multirow[t]{3}{*}{ all years } & Bxl + Wall & 340.972 & 354.964 & 49,0 & 44,8 & $-4,2$ & 1,3 & 1,2 & $-0,1$ & 31,9 & 36,9 & 5,0 & 17,8 & 17,1 & $-0,7$ \\
\hline & Bxl & 71.811 & 77.115 & 88,0 & 88,2 & 0,1 & 0,0 & 0,0 & $\mathbf{0 , 0}$ & 0,6 & 0,6 & $\mathbf{0 , 0}$ & 11,4 & 11,2 & $-0,2$ \\
\hline & Wall & 269.161 & 277.849 & 38,6 & 32,8 & $-5,8$ & 1,6 & 1,6 & $-0,1$ & 40,3 & 47,0 & 6,7 & 19,5 & 18,7 & $-0,8$ \\
\hline \multirow[t]{5}{*}{ Wall/province } & Brabant Wall & 29.156 & 29.919 & 73,5 & 67,6 & $-6,0$ & 0,0 & & $\mathbf{0 , 0}$ & 18,2 & 25,4 & 7,2 & 8,3 & 7,1 & $-1,2$ \\
\hline & Hainaut & 100.103 & 103.070 & 44,1 & 38,3 & $-5,8$ & 0,0 & & $\mathbf{0 , 0}$ & 33,0 & 40,6 & 7,6 & 22,9 & 21,1 & $-1,8$ \\
\hline & Namur & 40.713 & 42.098 & 43,7 & 34,9 & $-8,8$ & 0,0 & 0,0 & $\mathbf{0 , 0}$ & 32,9 & 42,0 & 9,1 & 18,4 & 23,1 & 4,7 \\
\hline & Liège & 74.775 & 77.284 & 22,3 & 18,1 & $-4,2$ & 4,9 & 4,5 & $-0,4$ & 56,1 & 60,0 & 3,9 & 16,7 & 17,4 & 0,6 \\
\hline & Luxembourg & 24.414 & 25.478 & 15,8 & 10,7 & $-5,2$ & 3,0 & 3,3 & 0,2 & 60,5 & 66,6 & 6,1 & 20,7 & 19,5 & $-1,2$ \\
\hline \multirow[t]{3}{*}{ 1st year only } & Bxl + Wall & 60.426 & 57.039 & 57,8 & 50,3 & $-7,5$ & 1,6 & 1,5 & $\mathbf{0 , 0}$ & 39,3 & 45,7 & 6,3 & 1,3 & 2,6 & 1,2 \\
\hline & Bxl & 13.729 & 13.117 & 96,9 & 94,9 & $-2,1$ & 0,0 & 0,0 & $\mathbf{0 , 0}$ & 0,0 & 0,0 & $\mathbf{0 , 0}$ & 3,1 & 5,1 & 2,1 \\
\hline & Wall & 46.697 & 43.922 & 46,3 & 37,0 & $-9,3$ & 2,0 & 2,0 & $\mathbf{0 , 0}$ & 50,9 & 59,3 & 8,4 & 0,9 & 1,8 & 0,9 \\
\hline \multirow[t]{5}{*}{ Wall/province } & Brabant Wall & 5.224 & 4.780 & 78,4 & 70,5 & $-7,9$ & 0,0 & 0,0 & $\mathbf{0 , 0}$ & 20,8 & 28,5 & 7,7 & 0,7 & 1,0 & 0,3 \\
\hline & Hainaut & 17.542 & 16.259 & 56,4 & 46,5 & $-9,9$ & 0,0 & 0,0 & $\mathbf{0 , 0}$ & 43,2 & 52,4 & 9,2 & 0,4 & 1,1 & 0,8 \\
\hline & Namur & 6.570 & 6.331 & 54,3 & 40,2 & $-14,2$ & 0,0 & 0,0 & $\mathbf{0 , 0}$ & 42,4 & 55,6 & 13,2 & 3,3 & 4,3 & 1,0 \\
\hline & Liège & 13.072 & 12.396 & 24,9 & 18,4 & $-6,5$ & 5,6 & 5,5 & $-0,1$ & 69,5 & 75,0 & 5,5 & 0,0 & 1,1 & 1,0 \\
\hline & Luxembourg & 4.289 & 4.156 & 18,5 & 11,5 & $-7,0$ & 4,8 & 4,5 & $-0,2$ & 75,4 & 80,4 & 5,0 & 1,3 & 3,6 & 2,3 \\
\hline
\end{tabular}

Source: Analyses based on data from ETNIC, Services statistiques de la Communauté française. 
Table 3: Distribution of the FL1, FL2 and FL3 in German-, Dutch- and French-medium secondary schools.

\begin{tabular}{|c|c|c|c|}
\hline & FL1 & FL2 & FL3 \\
\hline \multicolumn{4}{|c|}{ German-sp. area } \\
\hline 1st year & $\mathrm{Fr}$ & Eng & \\
\hline 2 nd year & $\mathrm{Fr}$ & Eng & \\
\hline $3 r d$ year & $\mathrm{Fr}$ & Eng & $\mathrm{Du}$ \\
\hline 4th year & $\mathrm{Fr}$ & Eng & $\mathrm{Du}$ \\
\hline 5 th year & Fr & Eng & $\mathrm{Du} / \mathrm{Sp}$ \\
\hline 6th year & $\mathrm{Fr}$ & Eng & $\mathrm{Du} / \mathrm{Sp}$ \\
\hline \multicolumn{4}{|c|}{ Dutch-sp. area } \\
\hline \multicolumn{4}{|c|}{ Flanders +} \\
\hline \multicolumn{4}{|c|}{ Brussels } \\
\hline 1st year & $\mathrm{Fr}$ & Eng & \\
\hline $2 n d$ year & Fr & Eng & \\
\hline $3 r d$ year & Fr & Eng & \\
\hline 4th year & $\mathrm{Fr}$ & Eng & \\
\hline 5 th year & Fr & Eng & Ger / Sp \\
\hline 6th year & Fr & Eng & Ger / Sp \\
\hline \multicolumn{4}{|c|}{ French-sp. area } \\
\hline \multicolumn{4}{|c|}{ Brussels } \\
\hline 1st year & Du / none & & \\
\hline $2 n d$ year & $\mathrm{Du} /$ none & & \\
\hline $3 r d$ year & $\mathrm{Du} /$ none & Eng & \\
\hline 4th year & $\mathrm{Du} /$ none & Eng & \\
\hline 5 th year & Du / none & Eng / Ger / Sp / (It) & Ger / Sp / It / Ru \\
\hline 6th year & Du / none & Eng / Ger / Sp / (It) & Ger / Sp / It / Ru \\
\hline \multicolumn{4}{|c|}{ French-sp. area } \\
\hline \multicolumn{4}{|c|}{ Wallonia } \\
\hline 1st year & $\begin{array}{c}\text { Eng / Du / Ger / } \\
\text { none }\end{array}$ & & \\
\hline 2nd year & $\begin{array}{c}\text { Eng / Du / Ger / } \\
\text { none }\end{array}$ & & \\
\hline $3 r d$ year & $\begin{array}{c}\text { Eng / Du / Ger / } \\
\text { none }\end{array}$ & $\begin{array}{c}\mathrm{Du} / \mathrm{Eng} / \mathrm{Ger} / \mathrm{Sp} / \\
\text { (It) }\end{array}$ & \\
\hline 4th year & $\begin{array}{l}\text { Eng / Du / Ger / } \\
\text { none }\end{array}$ & Du / Eng / Ger / Sp / & \\
\hline 5th year & $\begin{array}{c}\text { Eng / Du / Ger / } \\
\text { none }\end{array}$ & $\mathrm{Du} / \mathrm{Eng} / \mathrm{Ger} / \mathrm{Sp} / \mathrm{It}$ & $\begin{array}{c}\mathrm{Du} / \mathrm{Ger} / \mathrm{Sp} / \mathrm{It} / \\
\mathrm{Ru}\end{array}$ \\
\hline 6th year & $\begin{array}{c}\text { Eng / Du / Ger / } \\
\text { none }\end{array}$ & Du / Eng / Ger / Sp / It & $\begin{array}{c}\mathrm{Du} / \mathrm{Ger} / \mathrm{Sp} / \mathrm{It} / \\
\mathrm{Ru}\end{array}$ \\
\hline
\end{tabular}

$\mathrm{Fr}=$ French, Eng $=$ English, $\mathrm{Du}=$ Dutch, $\mathrm{Ger}=$ German, $\mathrm{Sp}=$ Spanish, $\mathrm{It}=\mathrm{Italian}, \mathrm{Ru}=$ Russian, none $=$ no FL at all. 
Table 4: Evolution of the CLIL programs in the Dutch-speaking Community since the start in 2014, split up by province.

\begin{tabular}{lcccccc}
\hline & $\mathbf{2 0 1 4 - 2 0 1 5}$ & $\mathbf{2 0 1 5 - 2 0 1 6}$ & $\mathbf{2 0 1 6 - 2 0 1 7}$ & $\mathbf{2 0 1 7 - 2 0 1 8}$ & $\mathbf{2 0 1 8 - 2 0 1 9}$ & $\mathbf{2 0 1 9 - 2 0 2 0}$ \\
\hline West-Vlaanderen & 7 & 13 & 20 & 27 & 34 & 43 \\
Oost-Vlaanderen & 7 & 9 & 17 & 24 & 30 & 37 \\
Antwerpen & 3 & 7 & 8 & 11 & 15 & 17 \\
Limburg & 5 & 7 & 9 & 9 & 11 & 13 \\
Vlaams-Brabant & 1 & 4 & 5 & 8 & 9 & 10 \\
Brussel & 1 & 1 & 1 & 2 & 2 & 4 \\
\hline New schools / & 24 & 17 & 19 & 21 & 20 & 23 \\
year & $\mathbf{2 4}$ & $\mathbf{4 1}$ & $\mathbf{6 0}$ & $\mathbf{8 1}$ & $\mathbf{1 0 1}$ & $\mathbf{1 2 4}$ \\
\hline Total & & & & & & \\
\hline
\end{tabular}

Source: Ministry of Education (July 2019) - https://onderwijs.vlaanderen.be/nl/clil-content-and-languageintegrated-learning\#Bottom [retrieved 19-08-2019]. 
Table 5: Evolution of the number of schools offering CLIL programs in the French-speaking Community from the start in 1998 until 2015-16, split up by educational level.

\begin{tabular}{rrrr}
\hline & (Pre-)primary & Secondary & Total \\
\hline $98-99$ & 3 & 0 & 3 \\
$99-00$ & 8 & 3 & 11 \\
$00-01$ & 18 & 4 & 22 \\
$01-02$ & 28 & 4 & 32 \\
$02-03$ & 37 & 4 & 41 \\
$03-04$ & 41 & 9 & 50 \\
$04-05$ & 62 & 14 & 76 \\
$05-06$ & 92 & 40 & 132 \\
$06-07$ & 109 & 53 & 162 \\
$07-08$ & 118 & 62 & 180 \\
$08-09$ & 131 & 76 & 207 \\
$09-10$ & 141 & 87 & 228 \\
$10-11$ & 156 & 97 & 253 \\
$11-12$ & 159 & 109 & 268 \\
$12-13$ & 167 & $*$ & \\
$13-14$ & 171 & 114 & 285 \\
$14-15$ & 155 & $*$ & \\
$15-16$ & 169 & 120 & 292 \\
\hline
\end{tabular}

* No data available for 2012-13 and 2014-15 for secondary schools. 
Table 6: Overview of starting moments, number of CLIL hours and percentages CLIL in weekly timetables.

\begin{tabular}{llllll}
\hline Level & Year & Starting age & Number CLIL h/week & Total h/week & \% CLIL \\
\hline Kindergarten & 3 rd & \pm 5 & $8<21$ & 28 & $28<75 \%$ \\
Primary & 1 st & \pm 6 & $8<21$ & 28 & $28<75 \%$ \\
& 3 rd & \pm 8 & $8<18^{*}$ & 28 & $28<64 \%$ \\
Secondary & 1 st & \pm 12 & $8<13^{* *}$ & 32 & $25<40 \%$ \\
& 3rd & \pm 14 & $8<13^{* *}$ & 32 or 36 & $25<40 \%$ \\
\hline
\end{tabular}

* Including regular FL classes from $5^{\text {th }}$ grade on.

** Including regular FL classes, with possibility to have extra-curricular activities in CLIL language. 
Table 7: Distribution of the schools in 2015-16, split up by target language and province $(\mathrm{N}=289)$.

\begin{tabular}{lrrrr}
\hline CLIL in & English & German & Dutch & N \\
\hline & & (Pre-)Primary & & \\
Brussels & & & 8 & 8 \\
Brabant wall. & 9 & & 25 & 34 \\
Hainaut & 20 & & 38 & 58 \\
Namur & 7 & 5 & 20 & 26 \\
Liège & 9 & 1 & 7 & 34 \\
Luxembourg & 1 & 6 & 117 & 169 \\
\hline Total & 46 & & & \\
\hline & & Secondary & 20 & 22 \\
Brussels & 2 & & 11 & 13 \\
Brab. wallon & 2 & & 18 & 28 \\
Hainaut & 10 & & 13 & 20 \\
Namur & 7 & & 11 & 27 \\
Liège & 12 & 4 & 6 & 10 \\
Luxembourg & 4 & & 79 & 120 \\
\hline Total & 37 & 4 &
\end{tabular}

Source: Statistical services Ministry of Education (ETNIC) - our analyses. 
Table 8: Distribution of the CLIL target languages amongst CLIL pupils in 2015-16, split up by education level, expressed in percentages $(\mathrm{N}=29.041)$.

\begin{tabular}{lrrrrr}
\hline & Kindergarten & Primary & Secondary & Total \% & $\mathrm{n}=$ \\
\hline English & 30,37 & 23,29 & 37,53 & 30,49 & 8.856 \\
German & 4,04 & 4,06 & 5,96 & 4,94 & 1.436 \\
Dutch & 65,59 & 72,64 & 56,51 & 64,56 & 18.749 \\
\hline
\end{tabular}

Source: Statistical services Ministry of Education (ETNIC) - our analyses. 